\title{
PERKEMBANGAN KOGNITIF, BAHASA, PERKEMBANGAN SOSIO-EMOSIONAL, DAN IMPLIKASINYA DALAM PEMBELAJARAN
}

\author{
Aniswita $^{1}$, Neviyarni ${ }^{2}$. \\ ${ }^{1}$ Ilmu Pendidikan, Universitas Negeri Padang \\ email: aniswitaumar@gmail.com \\ ${ }^{2}$ Universitas Negeri Padang \\ email: neviyarni.suhaili911@gmail.com
}

\begin{abstract}
Each individual must be progressing, even if they are relative. Development depends on the individual. Such developments include physical aspects and psychological aspects. Biological development concerns changes in the physical such as height, weight, skin color and others. While psychological development includes development on cognitive aspects, language and socio-emotional aspects. Cognitive development is a change that occurs in terms of thinking, children's intelligence is included in aspects of language, such as ability to solve mathematical problems, ability to master several languages, and others. Socioemotional development is a change that occurs in terms of interaction or relationship with others, such as changes in emotions. Many factors influence this development, including genetic factors or heredity factors and environmental factors, namely family, school and community. This development certainly has implications for the learning process. A professional and responsible educator or teacher must certainly pay attention to the development of his/her students. Both physical development, cognitive development, language and socio-emotional development. So that in learning teachers are able to treat learners according to their level of development. Teachers should be able to use various approaches and appropriate media to create learning that is conducive to the development of learners so that learning objectives can be achieved. Based on the exposure, the authors were interested to discuss more about the cognitive, language and socioemotional development of learners and their implications in learning.

Keywords: Cognitive, Language, Socio-Emotional Development
\end{abstract}

\begin{abstract}
Abstrak
Setiap individu pasti mengalami perkembangan, walaupun perkembangan itu bersifat relative. Perkembangan tergantung pada individu masing-masing. Perkembangan tersebut mencakup aspek fisik dan aspek psikologis. Perkembangan biologis menyangkut perubahan pada fisik seperti tinggi badan, berat badan, warna kulit dan lainnya. Sementara perkembangan psikologis mencakup perkembangan pada aspek kognitif, aspek bahasa dan sosio-emosional. Perkembangan kognitif adalah perubahan yang terjadi dalam hal pemikiran, kecerdasan anak termasuk dalam aspek bahasa, seperti kemampuan dalam memecahkan masalah matematika, kemampuan menguasai beberapa bahasa, dan lainnya. Perkembangan sosio-emosional adalah perubahan yang terjadi dalam hal interaksi atau hubungan dengan orang lain, seperti perubahan pada emosi. Banyak faktor yang mempengaruhi perkembangan ini, diantaranya adalah faktor genetik atau faktor hereditas dan faktor lingkungan yaitu keluarga, sekolah dan masyarakat. Perkembangan ini tentu berimplikasi pada proses pembelajaran. Seorang pendidik atau guru yang professional dan bertanggung jawab tentu harus memperhatikan perkembangan peserta didiknya. Baik perkembangan fisik, perkembangan kognitif, bahasa maupun perkembangan sosio-emosionalnya. Sehingga dalam pembelajaran guru mampu memperlakukan peserta didik sesuai dengan tingkat perkembangnya. Guru seyogyanya mampu menggunakan berbagai pendekatan dan media yang tepat demi
\end{abstract}


terciptanya pembelajaran yang kondusif untuk perkembangan peserta didik sehingga tujuan pembelajaran dapat dicapai. Berdasarkan paparan tersebut penulis tertarik untuk membahas lebih lanjut tentang perkembangan kognitif, bahasa dan sosio-emosional peserta didik serta implikasinya dalam pembelajaran.

Keywords: Perkembangan, kognitif, sosio-emosional, Implikasi dalam pembelajaran

\section{PENDAHULUAN}

Perkembangan dapat didefinisikan sebagai suatu pola perubahan. Perubahan ini meliputi aspek fisik, aspek kognisi dan aspek sosioemosional. Perubahan ini terjadi sejak manusia lahir dan berlansung sepanjang hidupnya (Santrock, 2004). Senada dengan pendapat Santrock, I Nyoman Surna dkk mengatakan perkembangan itu sebagai perubahan yang bersifat kuantitatif dan kualitatif (Surna $\&$ Pandeirot, 2014). Perubahan kuantitatif mengacu pada perubahan kuantitas atau jumlah, sedangkan perubahan kualitatif mengacu pada perubahan struktur atau jenis yang ditandai dengan munculnya fenomena atau gejala baru yang sulit diprediksi. Sumadi Surya Brata menambahkan bahwa perubahannya ke arah yang lebih maju, lebih dewasa dan perubahan itu adalah suatu proses. Pendapat ini diperkuat oleh Muhibbin Syah yang mengatakan bahwa perubahan itu pada hakikatnya merupakan penyempurnaan fungsi psikologis dari organ fisik, proses ini terjadi sampai akhir hayat (Syah, 2009).

Menurut aliran Asosiasi, perkembangan adalah proses asosiasi yaitu pengalaman luar dan pengalaman dalam berasosiasi memberikan pengertian terhadap sesuatu yang baru. Berbeda dengan aliran Asosiasi, Psikologi Gestalt lebih menekankan perkembangan sebagai sebuah proses diferensiasi yaitu pengertian sesuatu diperoleh ketika seseorang mampu membedakannya dengan yang lain. Aliran New Gestalt menambahkan dengan adanya proses stratifikasi atau bertingkat. Sedikit berbeda, aliran Sosiologis mengangap bahwa perkembangan merupakan suatu proses sosialisasi yaitu anak-anak meniru atau menyesuaikan tingkah laku atau perbuatannya dengan aturan atau norma sosial yang berlaku (Brata, 2001). Ketiga aliran ini sama-sama memandang perkembangan merupakan sebuah proses penyempurnaan ke arah yang lebih baik tetapi masing-masing aliran menekankan perubahan itu terjadi akibat yang berbeda yaitu asosiasi, diferensiasi dan sosialisasi. Jadi berdasarkan pendapat ahli dan beberapa aliran psikologi di peroleh kata kunci dari perkembangan yaitu merupakan suatu proses, perubahan itu terjadi ke arah yang lebih baik, dan terjadi sepanjang hayat. Perkembangan meliputi perubahan kuantitatif dan kualitatif pada aspek biologis dan aspek psikologis.

Proses perkembangan sangat komplek, karena merupakan hasil dari proses perubahan yang meliputi tiga aspek yaitu proses biologi, proses kognitif dan proses sosio-emosional (Santrock, 2004). Proses biologis adalah perubahan pada tubuh atau fisik anak seperti tinggi, berat badan, perkembangan otak, perubahan hormonal di masa puber dan lainnya. Proses biologis dipengaruhi oleh faktor genetik atau hereditas yang dibawa dari lahir dan juga faktor lingkungan seperti asupan gizi, perawatan, obat-obatan atau faktor cedera. Selain itu pola asuh juga berpengaruh terhadap perkembangan ini. Proses kognitif merupakan perubahan dalam pemikiran, kecerdasan atau intelektual anak termasuk dalam aspek bahasa. Contohnya kemampuan anak dalam memecahkan masalah matematika, kemampuan aspek menguasai beberapa bahasa, kemampuan main bulu tangkis, dan lainnya. Faktor ini juga dominan dipengaruhi oleh factor genetik dan adanya pengaruh dari lingkungan. Sedangkan Proses sosio-emosional berhubungan dengan perubahan dalam interaksi dengan orang lain seperti terjadinya perubahan emosi pada diri anak, yang awalnya egois berubah menjadi empati dan bisa diajak 
kerjasama serta memiliki kecerdasan emosional. Proses sosio-emotional juga sangat dipengaruhi oleh pola asuh dan lingkungan termasuk budaya.

Seorang guru harus memahami perkembangan peserta didiknya. Pendidikan harus dirancang sesuai dengan tingkat perkembangan anak, sehingga proses pembelajaran menjadi lebih optimal. Tingkat perkembangan dapat dilihat dari Periodesasi perkembangan dimulai dari periode Infancy (18-24 bulan), periode ini anak sangat tergantung pada pola pengasuhan orang tua. Bayi mulai belajar bicara, bersosialisasi. Periode kedua Early Childhood (2-5 tahun), periode ini disebut juga dengan masa prasekolah. Anak sudah mulai memiliki kemampuan, kesiapan dan mulai mengerti dengan arahan atau petunjuk. Periode ini anak sudah bersosialisasi dengan teman-temannya dengan cara bermain bersama. Periode ketiga Middle and late Childhood (6-11 tahun) disebut juga dengan masa sekolah. Anak sudah siap untuk belajar membaca, berhitung dan belajar matematika. Periode keempat Adolecence (10-12 berakhir 18-21 tahun). Periode ini disebut juga dengan masa remaja atau peralihan dari masa anak-anak ke masa dewasa. Pada periode ini terjadi perubahan yang sangat signifikan pada fungsi tubuh diantaranya berkembangnya fungsi seksual. Periode ini disebut juga dengan periode pancaroba dimana anak sedang mencari jatidiri. Anak sudah mulai mengembangkan pemikiran abstrak serta berfikir logis dan idealis (Surna \& Pandeirot, 2014).

Terdapat beberapa prinsip yang mempengaruhi proses perkembangan yaitu: pembelajaran, pengalaman, interaksi sosial, penguasaan bahasa dan berlansung secara berkelanjutan, irama dan tempo perkembangan, kematangan, faktor genetik dan usia (Surna \& Pandeirot, 2014). Dari uraian di atas penulis tertarik membahas tentang perkembangan pada aspek psikologis yaitu perkembangan kognitif, bahasa, dan sosio-emotional serta implikasinya dalam pembelajaran.

\section{METODOLOGI}

Penulisan artikel, menggunakan metode studi pustaka atau studi literature. Objek yang dikaji dalam tulisan ini adalah perkembangan pada aspek psikologis yang meliputi aspek kognitif termasuk bahasa dan sosioemosional anak. Ketiga aspek ini sangat signifikan dalam menentukan proses pembelajaran seorang anak.

\section{HASIL PENELITIAN DAN PEMBAHASAN Perkembangan Kognitif}

Kata kognitif atau "cognition" secara etimologi merupakan bahasa Inggris yang bersinonim dengan "Knowing" atau mengetahui. Sedangkan pengertian kognisi lebih luas adalah bagaimana memperoleh, menyusun, dan menggunakan suatu pengetahuan. Hal ini didukung oleh pendapat Caplin dalam Muhibbin Syah yang mengatakan bahwa kognitif merupakan semua perilaku mental yang terpusat di dalam otak dan memiliki hubungan dengan kehendak atau konasi dan dengan perasaan atau afeksi. Perilaku mental ini mencakup bagaimana seseorang memahami atau memberi pertimbangan terhadap sesuatu, bagaimana penata atau mengelola informasi untuk memecahkan masalah atau kesenjangan serta menguatkan keyakinan (Syah, 2009). Secara singkat Santrock mengatakan bahwa kognisi sama juga dengan pemikiran. Jadi berdasarkan uraian di atas kognisi atau kognitif dapat diartikan sebagai kemampuan yang berpusat pada otak dan berhubungan dengan pemikiran.

Proses perkembangan kognitif erat kaitanya dengan proses perkembangan otak. Berbagai penelitian dilakukan untuk melihat bagaimana perubahan otak terjadi mulai dari masa kanak-kanak sampai dewasa. Masih banyak yang belum 
diketahui dari proses perkembangan otak tersebut, seperti yang dikatakan Blair bahwa sampai dewasa ini penelitian yang dilakukan belum mampu mengungkap perubahan masalah otak begitu juga dengan hubungan antara perkembangan otak dengan pendidikan anak. Syaraf otak terus berkembang setidaknya sampai usia remaja, dan perkembangan maksimal itu terjadi saat masa kanak-kanak. Terkait dengan perkembangan syaraf ini ada beberapa istilah yaitu myelination Synapse, dan lateralisasi (Santrock, 2004).

Myelination merupakan suatu kondisi atau proses dimana lemak yang bersekat-sekat menyelimuti sel otak dan sel syaraf. Myelination penting untuk menfokuskan atau memusatkan perhatian anak. Proses ini belum lengkap pada saat anak masih usia pra sekolah, sehingga anak-anak prasekolah mudah teralihkan perhatianya dan tidak bisa betah dengan satu aktivitas. Synapsis merupakan jarak yang sangat tipis atau disebut juga dengan gap antara neuron. Koneksi ini terbentuk lebih banyak dari yang dipakai sehingga sisanya akan dihapus atau dipangkas. Puncak kelebihan synapsis khususnya di area prefrontal (tempat penalaran dan pengaturan diri) pada usia satu tahun sedangkan kepadatannya sampai usia 18 tahun. Menurut Thomson, penelitian menunjukkan bahwa perubahan anatomi otak (bukan ukuran) subtansial berlansung dari usia 3-15 tahun. Dari empat cuping (bagian) otak, bagian cuping frontal khususnya perhatian berkembang dari usia 3-6 tahun. Sedangkan cuping temporal yang bertanggung jawab terhadap memori jangka panjang atau long time memory dan tempat pengolahan bahasa. Cuping parietal (spasial) berkembang dari usia enam tahun sampai mendekati masa puber atau remaja (Santrock, 2004). Lateralisasi adalah spesialisasi antara satu belahan otak dengan belahan lainnya. Menurut Gazzaniga dkk terdapat dua belahan otak yaitu otak kiri yang terkait dengan pemprosesan non verbal lebih cenderung keberfikir logis dan otak kanan terkait dengan pemprosesan verbal lebih cenderung ke kreatif. Tapi dalam pemprosesan informasi sering melibatkan komunikasi antara keduanya. Dengan kata lain otak kiri dan kanan tidak berdiri sendiri-sendiri tapi saling berhubungan dalam mengolah informasi.

\section{Teori perkembangan kognitif Piaget}

Jean Piaget adalah tokoh utama yang melahirkan teori perkembangan kognitif. Awalnya Jean Piaget adalah seorang ahli biologi berkebangsaan Swiss. Beliau lahir di Swiss pada tahun 1896 dan meninggal dalam usia 84 tahun. Teori perkembangan kognitif Piaget menjadi dasar perkembangan konsep kecerdasan dalam Psikologi yang dijadikan rujukan atau acuan. Terdapat lima konsep dasar yang menjadi acuan dari teori perkembangan kognitif Piaget yaitu: Konsep skema, proses Asimilasi, proses Akomodasi, dan proses Organisasi serta proses Ekuilibrasi. Skema merupakan kerangka atau konsep dasar dalam fikiran anak yang bertujuan untuk mengorganisasi atau menata informasi serta menginterprestasikanya. Terdapat dua konsep atau proses yang terlibat yaitu proses asimilasi dan akomodasi. Asimilasi dan akomodasi merupakan proses mental yang tidak bisa diamati secara lansung tetapi terjadi dalam kognisi anak. Asimilasi merupakan proses ketika anak atau individu memasukkan pengetahuan baru ke dalam kerangka pengetahuan lama yang sudah ada. Sedangkan Akomodasi merupakan proses ketika anak beradaptasi dengan informasi baru yang diterimanya (Santrock, 2004). Contohnya seorang anak baru belajar bersepeda. Dia mengamati orang memakai sepeda kemudian anak tersebut memasukkannya ke dalam skema yang sudah dia miliki, proses ini disebut dengan proses asimilasi. Ketika dia menaiki sepeda dan terjatuh dia berusaha menyesuaikan diri, proses ini yang disebut 
dengan proses akomodasi.

Menurut Piaget, dalam memahami dunia, seorang anak harus mengorganisasi informasi yaitu pengelompokan atau menata informasi tersebut ke dalam sistem kognitif yang lebih teratur sehingga meningkatkan kemampuan memori jangka panjang. Analoginya seperti menyusun baju dalam lemari ketika ditata dengan rapi maka akan mudah mengambil baju itu jika dibutuhkan. Ekuilibrasi merupakan proses atau mekanisme pemikiran anak yang bergeser dari suatu tahap ke tahap pemikiran selanjutnya yang lebih komplek. Proses ini terjadi karena anak mengalami semacam konflik dalam kognisi anak atau disebut juga dengan proses disekuilibrium untuk memahami informasi atau sesuatu yang baru. Ketika anak berhasil memecahkan konflik tersebut maka terjadilah sebuah keseimbangan dalam pemikiran sehingga anak mendapatkan pengetahuan baru (Santrock, 2004). Contohnya ketika seorang anak bingung kenapa air bentuknya berubah-ubah sesuai dengan wadahnya dan dia berhasil memecahkanya saat itulah proses ekuilibrasi terjadi dan anak mendapatkan pemahaman atau pengetahuan baru. Jadi dapat disimpulkan bahwa anak akan mendapat pengetahuan baru jika terjadi proses Ekuilibrasi dalam diri anak tersebut. Hal ini ditegaskan oleh pendapat Wasty Soemanto yang mengatakan bahwa anak akan mencapai tingkat perkembangan intelektual yang maksimal jika individu atau anak tersebut bisa menjaga proses Ekuilibrasi dalam dirinya (Soemanto, 2006)

Selanjutnya Jean Piaget membagi tahap perkembangan kognisi anak kedalam empat periode perkembangan. Pembagian tersebut didasarkan pada pertambahan usia anak, artinya semakin bertambah usia anak maka akan semakin berkembang kognitifnya. Periode tersebut yaitu: Periode sensorimotor, periode praoperasional, periode operasional konkrit, periode operasional formal (Santrock, 2004).

\section{Periode atau tahap Sensorimotor (0-2 tahun).}

Karakteristik periode sensorimotor menurut Piaget adalah membangun dan mengorganisasikan pengalaman indra atau sensory dengan gerakan motorik atau otot. Periode ini dibagi dalam enam sub-tahapan yaitu :

1) Sub-tahap pertama adalah fase skema refleks, pada fase ini karakteristiknya terutama berkaitan dengan gerakan reflek atau spontan yang dilakukan anak di awal-awal fase kehidupanya. Fase ini di mulai sejak lahir sampai anak berusia enam minggu. Contohnya anak menangis ketika merasa tidak nyaman.

2) Sub-tahap kedua adalah fase reaksi sirkular primer, pada fase ini karakteristiknya terutama berkaitan dengan munculnya kebiasaan-kebiasaan atau pola-pola tertentu pada anak. Fase ini dimulai dari usia enam minggu sampai empat bulan. Contohnya anak sudah mulai bergerak menggapai gapai sesuatu.

3) Sub-tahap ketiga adalah fase reaksi sirkular sekunder, pada fase ini karakteristiknya terutama berkaitan dengan koordinasi antara penglihatan dan pemaknaan. Fase ini dimulai sejak usia empat bulan sampai sembilan bulan. Contohnya anak mulai tertarik melihat benda berwarna warni.

4) Sub-tahap keempat adalah fase koordinasi reaksi sirkular sekunder, pada fase ini karakteristiknya terutama berkembangnya kemampuan anak dalam melihat suatu benda sebagai sesuatu yang tetap atau disebut juga dengan permanensi objek. Fase ini muncul dari usia sembilan sampai usia duabelas bulan. Contohnya anak bisa melihat boneka adalah objek yang sama walaupun dilihat dari samping dari atas, dari depan ataupun dari belakang.

5) Sub-tahap kelima adalah fase reaksi sirkular tersier, pada fase ini karakteristiknya terutama berkaitan dengan anak menemukan cara-cara baru 
untuk mencapai tujuannya. Fase ini muncul saat anak berusia satu tahun sampai berusia satu tahun setengah atau delapan belas bulan. Contohnya anak sudah bisa meraih sesuatu dengan bantuan benda sekitarnya.

6) Sub-tahap keenam adalah fase representasi simbolik awal, pada fase ini berkaitan dengan mulainya proses kreativitas dalam diri anak. Fase ini muncul dari usia delapan belas bulan sampai dua tahun. Contohnya anak sudah mulai bisa menyusun balok warna warni, dan lainnya.

\section{Periode atau tahap Praoperasional (2-7tahun)}

Periode praoperasional berlansung pada anak usia dua tahun sampai usia tujuh tahun. Pada periode ini lebih bersifat simbolis dibandingkan periode pertama atau periode sensorimotor. Tetapi pada tahap ini belum melibatkan pemikiran operasional. Jadi karakteristik dari periode ini adalah proses mental yang masih mengandalkan intuitif atau perasaan bukan logika. Pada perode ini, anak mulai belajar merepresentasikan atau menampilkan objek dengan menggunakan katakata, symbol atau gambar. Pemikiran anak masih bersifat egosentris atau berpusat pada dirinya dengan kata lain anak belum bisa melihat sesuatu berdasarkan pandangan orang lain. Anak sudah mampu mengklasifikasikan benda yang memiliki karakteristik tertentu. Contohnya anak bisa mengelompokkan balok dengan balok, bola dengan bola walaupun warna balok dan bola berbeda-beda.

Menurut Santrock periode praoperasional dapat dibedakan menjadi dua sub tahap. Tahap atau fase tersebut adalah:

1) Fase fungsi simbolis berlansung dari usia dua sampai empat tahun

Pada tahap atau fase ini kemampuan simbolis anak semakin berkembang dengan baik. Anak mampu merepresentasikan atau menggambarkan objek yang tidak hadir dengan menggunakan simbol atau gambar. Selain itu dalam memahami sesuatu anak masih cenderung egosentris dan animism. Simbolis maksudnya adalah mensimbolkan atau mempresentasikan objek dalam bentuk lukisan atau tepatnya coretan-coretan. Contohnya anak menggambar mobil, matahari, tapi bentuknya aneh dan khayalan, tidak sesuai dengan keadaan sebenarnya, mobil menggantung, matahari digambarkan berwarna hijau dan lainnya. Dikatakan bahwa lukisan anak kecil seperti lukisan abstrak pada lukisan modern. Pablo Picasso mengatakan bahwa beliau bisa menggambar seperti gambar Raphael, tetapi butuh waktu seumur hidup untuk dapat menggambar seperti yang dilakukan anak kecil. Egosentris adalah ketidakmampuan anak untuk membedakan sudut pandang milik sendiri dan sudut pandang orang lain. Piaget dan Barbel Inhelder (1969) menyelidikinya dengan percobaan seorang anak dihadapkan pada pemandangan dan satu boneka juga digerakkan di sekitar pemandangan. Ketika anak ditanya pemandangan yang dilihat boneka, anak tersebut menjawab berdasarkan pemandangan yang dilihatnya. Animisme adalah suatu kepercayaan atau anggapan bahwa objek atau benda mati dapat bergerak dan bisa hidup, sehingga anak ketika terjatuh karena menyenggol meja, mereka menganggap mejalah yang mendorongnya.

2) Fase pemikiran intuitif berlansung dari usia empat tahun samapai tujuh tahun Pada tahap atau fase ini anak sudah mulai menggunakan penalaran, tetapi penalaranya masih bersifat primitif dan rasa ingin tahu anak semakin berkembang. Mereka menuntut jawaban atas semua pertanyaanya. Hal inilah yang menjadi alasan kenapa anak sering sekali bertanya dan ingin tahu. Anakanak merasa yakin dan benar dengan pengetahuanya, padahal pengetahuan tersebut diperoleh bukan dari pemikiran rasional. Karakteristik pemikiran pada tahap ini adalah "centration" dan kurangnya "conservation". Centration adalah 
pemusatan atau menfokuskan perhatian pada suatu karakteristik atau ciri dari suatu objek dan mengabaikan ciri yang lain. Sedangkan conservation merupakan ide bahwa beberapa karakteristik atau ciri dari objek tetap sama meskipun objek tersebut berubah bentuknya. Selain itu pada fase ini menurut Piaget walaupun anak sudah memiliki pemikiran intuitif tapi pada fase ini anak belum bisa melakukan operasi. (Santrock, 2004).

\section{Periode Operasional Konkrit dari usia tujuh tahun sampai sebelas tahun}

Periode ini anak sudah memiliki pemikiran operasional konkret. Operasional konkret tersebut meliputi penggunaan operasi dan penalaran sudah menggunakan logika dalam situasi konkret. Anak tidak lagi menggunakan penalaran intuitif dan anak sudah bisa mengelompokkan atau mengklasifikasikan objek konkret. Operasi konkret merupakan operasi yang berkaitan dengan objek konkret atau nyata. Jadi berdasarkan uraian di atas terlihat anak yang ada pada fase operasional konkrit, anak sudah bisa bernalar tapi masih pada persoalan atau permasalahan konkrit atau nyata. Contohnya anak sudah memahami bahwa air bentuknya sesuai dengan wadahnya jadi walaupun air dipindah-pindahkan ke dalam beberapa wadah bentuknya berubah tapi volumenya tetap.

Kemampuan operasional yang paling penting pada periode ini adalah pengklasifikasian atau mengelompokkan objek konkret berdasarkan sub bagian yang berbeda dan dapat memahami hubungannya. Contoh anak pada tahap ini sudah bisa mengklasifikasikan ranji keluarga dan memahami hubungan diantara anggota keluarga. Selain mengklasifikasikan, anak juga sudah bisa mengurutkan objek yang disebut dengan istilah "seriation". Contohnya ketika anak diberi beberapa tali yang ukuran panjangnya berbeda maka anak dapat mengurutkanya dari pendek ke panjang atau sebaliknya. Sedangkan hubungan antar sub bagian yang disebut dengan "transitivity" menurut piaget pada periode ini sudah bisa dipahami anak. Contohnya ketika anak memiliki 3 utas tali yang panjangnya berbeda, anak bisa memahami jika tali A lebih panjang dari B dan tali B lebih panjang dari $\mathrm{C}$ maka tali A lebih panjang dari tali C. Jadi pada periode operasional konkret, anak sudah mampu menggunakan penalaranya pada objek konkret.

\section{Periode Operasional Formal dari usia 11 tahun sampai Dewasa}

Periode ini anak sudah memiliki kemampuan untuk bisa berpikir di luar hal yang konkret atau disebut juga dengan berfikir abstrak, idealis dan menalar secara logis, serta dapat menarik sebuah kesimpulan. Pada tahap operasional formal ini, anak dapat memahami objek abstrak seperti cinta, kasih sayang, dan nilai. Kualitas berfikir abstrak dapat dilihat dari kemampuan anak memecahkan masalah verbal, anak tidak butuh lagi benda konkret. Selain abstraksi, anak pada periode ini juga memiliki kemampuan untuk melakukan idealisasi dan kemampuan mempredikasi segala kemungkinan. Saat bersamaan anak juga mulai berfikir secara logis. Jadi anak sudah bisa menyusun rencana secara sistematis dalam memecahkan masalahnya, proses ini yang disebut Piaget dengan "penalaran hipotetis deduktif".

\section{Teori Perkembangan Kognitif Vygotsky}

Lev Vygotsky lahir tahun 1896 dan meninggal tahun 1934. Beliau merupakan tokoh perkembangan kognitif berkebangsaan Rusia yang percaya bahwa anak aktif dalam menyusun atau mengkonstruksi pengetahuan mereka. Lev Vygotsky menyandarkan teori kognitifnya pada tiga asumsi dasar yaitu:

1) Kemampuan kognisi anak dapat dipahami jika kemampuan tersebut dianalisa dan diinterprestasikan sebagai suatu proses perkembangan atau developmental. Maksudnya dalam memahami kognitif anak harus dipahami sebagai 
perkembangan dari suatu tahap ketahap berikutnya yang lebih komplek.

2) Kemampuan kognisi di mediasi oleh kemampuan bahasa atau bahasa merupakan alat terpenting dalam membantu anak mengembangkan kemampuan kognitifnya.

3) Kemampuan kognisi diperoleh dari relasi atau hubungan sosial yang dipengaruhi oleh latar belakang sosial kultural. Jadi perkembangan kemampuan kognitif tidak bisa dipisahkan dari kegiatan sosial kultural.

Sesuai dengan asumsi tersebut, Vygotsky mengajukan sebuah konsep tentang belajar yang disebut dengan Zone of Prokximal Development atau disingkat dengan ZPD. ZPD merupakan serangkaian atau sekumpulan tugas dengan batas yang dapat dikerjakan anak dan jika anak tidak bisa mengerjakan sendiri tapi tugas tersebut bisa dikerjakan dengan dibantu oleh orang dewasa atau teman sebaya yang lebih mampu. Jadi penekanannya ada pada pengaruh sosial terhadap kecerdasan anak. Sesuai dengan konsep ZPD tersebut ada istilah scaffolding sebuah teknik untuk mengubah dukungan. Contohnya ketika anak tidak paham tentang perkalian maka guru atau teman dapat membantu anak tersebut dengan meminta anak melakukan penjumlahan secara berulang sampai ditemukan hasil perkalian. Menurut Vygotsky anak sebenarnya sudah kaya dengan konsep tapi belum sistematis dan teratur makanya diperlukan bantuan orang dewasa atau yang sudah ahli di konsep tersebut. Selain itu Vygotsky menganggap bahwa perkembangan kognitif sangat dipengaruhi oleh faktor bahasa. Pandangan inilah yang membedakan teori Piaget dan Vygotsky.

\section{Perkembangan Bahasa}

Bahasa merupakan alat untuk berkomunikasi bisa berupa lisan, tulisan atau isyarat. Semua bahasa merupakan hasil ciptaan manusia. Beberapa konsep yang terkait dengan bahasa adalah fonologi, morfologi, semantik, dan prakmatis. Fonologi adalah sistem suara bahasa contohnya bunyi suara "k" pada kata $s k i$, cat dan lainnya. Morfologi adalah aturan untuk mengkombinasikan morfem atau suku kata dan ini merupakan kesatuan bahasa terkecil. Contohnya "help" merupakan satu morfem, "helper" terdiri dari dua morfem. Sintaksis merupakan cara kata untuk membentuk suatu frasa atau kalimat yang bermakna dan bisa dipahami. Contohnya Ayah membantu Ibu. Semantik adalah makna dari kata atau kalimat yang diterima. Contohnya wanita dan perempuan memiliki makna kata yang sama yaitu manusia yang berjenis kelamin perempuan. Pragmatis adalah penggunaan percakapan yang tepat. Menurut Nakamura, untuk bisa menggunakan percakapan yang tepat maka seseorang harus bisa memahami apa yang dikatakan, kepada siapa perkataan itu ditujukan dan bagaimana cara mengatakannya (Santrock, 2004). Kalimat yang sama tetapi jika kontek berbeda maka akan menghasilkan makna yang berbeda. Contohnya ketika anak mengucapkan kata kamu ketemannya tidak apa-apa tapi ketika diucapkan kepada orang yang lebih tua maka kata tadi tidak tepat karena dianggap tidak sopan. Jadi untuk bisa berbahasa dengan efektif, perlu diperhatikan aturan-aturan tentang bahasa yang baik.

Perkembangan bahasa dipengaruhi oleh beberapa faktor diantaranya adalah faktor biologis, faktor pengalaman dan juga faktor budaya. Contohnya, berdasarkan beberapa penelitian, terlihat anak yang terlahir dan dibesarkan dari keluarga sosial ekonomi menengah ke atas cenderung memiliki bahasa yang lebih halus dan santun. Begitu juga dengan anak yang lahir dan dibesarkan dalam keluarga sosial ekonomi menengah ke bawah cenderung memiliki bahasa kasar dan kurang santun. Jadi lingkungan cukup berperan penting dalam perkembangan bahasa anak. Sedikit berbeda Hoff (2001) mengatakan bahwa perkembangan bahasa anak tidak bisa hanya dijelaskan dengan kerangka lingkungan saja. Noam Chomsky, seorang ahli 
bahasa menambahkan bahwa anak atau manusia mempelajari bahasa pada waktu tertentu dengan cara tertentu. Hal ini dibuktikan dengan anak-anak diseluruh dunia hampir bersamaan mencapai titik penting dalam kemampuan. Perkembangan bahasa berkorelasi positif dengan tingkat perkembangan kognisi mereka.

Pertanyaan penting dalam perkembangan bahasa adalah hubungan antara kemampuan bahasa dan kemampuan kognitif. Ahli berbeda pendapat dan terbagi ke dalam bipolar yang mengatakan bahwa kemampuan bahasa penting untuk perkembangan kognisi dan kemampuan kognisi penting untuk perkembangan kemampuan bahasa. Sebagian ahli berpendapat perkembangan bahasa dan perkembangan kognisi anak terjadi secara bersamaan dan terpisah atau independen. Hal ini terlihat dari studi terhadap anak yang tuli tidak bisa berbahasa tetapi secara kognisi mereka hampir sama dengan anak seusianya yang normal pendengarannya. Jadi dapat diambil suatu kata kunci yaitu adanya keterkaitan antara kemampuan bahasa dan kemampuan kognitif. Seseorang yang memiliki kecerdasan kognitif juga memiliki kemampuan bahasa yang baik begitu juga sebaliknya dengan kata lain perkembangan bahasa dan perkembangan kognisi berkorelasi positif.

\section{Teori Perkembangan Bahasa Anak}

Bahasa adalah bagian penting dalam kehidupan manusia karena bahasa digunakan untuk berkomunikasi. Semakin baik penguasaan bahasa anak semakin baik komunikasi dan interaksinya dengan orang lain. Tahap perkembangan Bahasa yang terjadi pada anak menurut beberapa ahli diantaranya adalah:

\section{1) Lundsteen}

Menurut Lundsteen, perkembangan bahasa anak dibagi dalam tiga periode atau tahap, yaitu: Tahap pertama adalah tahap pralinguistik, terjadi pada anak baru lahir sampai usia dua belas bulan atau satu tahun. Pada usia sampai tiga bulan, anak sudah bisa mengeluarkan suara yang keluar dari tenggorokan. Pada usia tiga bulan sampai dua belas bulan, anak sudah bisa mengeluarkan suara yang keluar dari bibir dan langit-langit, misalnya pa, ma, ba. Tahap kedua adalah tahap protolinguistik terjadi pada usia dua belas bulan sampai dua tahun. Tahap ini anak sudah mampu mengenali dan menunjukkan anggota tubuhnya. Anak mulai berbicara beberapa patah kata, seperti ma-kan, ma-ma dan lainnya. Kosa kata anak dapat mencapai 200-300 kata. Tahap ketiga adalah tahap linguistik terjadi pada anak usia dua tahun sampai enam tahun. Tahap ini anak mulai belajar tata bahasa atau gramatika dan perkembangan kosa kata anak mencapai 3000 kosa kata.

2) Bzoch

Menurut Bzoch, perkembangan kemampuan bahasa anak dari lahir sampai usia 3 tahun dibagi menjadi empat periode yaitu: Periode pertama adalah periode Prelinguistik, periode ini terjadi ketika anak baru lahir sampai berusia tiga bulan. Anak belum bisa mengucapkan kata atau ucapan yang bermakna dan biasanya komunikasi lebih bersifat reflek atau spontan seperti suara tangisan atau bunyibunyi lain yang tidak teratur yang keluar dari kerongkongan anak. Periode kedua adalah periode kata - kata pertama terjadi pada anak usia tiga sampai sembilan bulan. Anak sudah mulai mengeluarkan kata yang bermakna, seperti kata ma, na, pa dan lainnya. Periode ketiga adalah periode transisi ke bahasa anak, periode ini berlansung dari usia sembilan bulan sampai delapan belas bulan. Periode ini terjadi pertumbuhan kosa kata dengan sangat cepat. Anak sudah mulai mengucapkan kalimat awal, anak biasanya menggunakan kata dari benda-benda dan orang disekitarnya. Begitu juga dengan kejadian-kejadian di lingkungannya. 
Perkembangan puncak dan menyeluruh terjadi pada usia delapan belas bulan. Contoh ka-kak, ma-ma, pa-pa, dan lainnya. Periode keempat adalah periode bahasa anak, mereka mulai bisa mengucapkan kalimat sederhana dengan merangkai subjek dan predikat yang kemudian menghasilkan suatu kalimat yang bermakna, contohnya Ayah pergi, mama memasak. Melalui interaksi dengan orang-orang disekelilingnya, anak mulai belajar menggunakan bahasa dalam percakapannya sehari-hari. Seiring dengan perkembangan kognitif, anak mulai bisa berkomunikasi atau berbicara dengan menggunakan kata-kata yang sudah ada dalam memori atau ingatannya. Kemampuan bahasa anak sudah mulai menyerupai bahasa orang dewasa. Terjadi perubahan signifikan dalam kemampuan berbahasa anak dengan kata lain terjadi perubahan dari bahasa bayi ke bahasa anak pra sekolah yang menyerupai bahasa orang dewasa. Periode ini terjadi pada usia 18 bulan sampai 36 bulan. Pada masa ini anak sudah mulai berpikir tetapi masih menggunakan atau mengandalkan intuisi, anak sudah mulai bisa mengelompokkan benda, orang, dan peristiwa serta dapat menyelesaikan masalah-masalah konkrit yang sederhana.

3) Santrock

Santrock membagi perkembangan bahasa anak dalam sebelas periode yaitu: periode pertama terjadi saat anak baru lahir sampai anak berusia enam bulan. Cirinya bayi mengeluarkan suara-suara yang tidak jelas, membedakan huruf hidup, dan pada akhir periode mungkin terdengar anak seperti berceloteh. Periode kedua berlansung saat anak berusia enam sampai 12 bulan. Cirinya celoteh anak semakin bertambah, anak sudah mulai bisa menggunakan isyarat untuk mengkomunikasikan objek. Periode ketiga terjadi pada anak usia dua belas sampai delapan belas bulan. Cirinya anak sudah mulai mengucapkan kata pertama, seperti ma, da, pa, dan lainnya, rata-rata anak sudah dapat memahami kurang lebih 50 kata. Periode keempat berlansug dari usia delapan belas sampai dua puluh empat bulan, kosakata anak semakin bertambah sampai mencapai 200 kata, anak sudah bisa mengkombinasikan atau menggabungkan dua kata seperti mama, papa, dan lainnya. Periode kelima berlansung pada saat usia anak dua tahun, kosakata anak bertambah dengan sangat cepat. Anak sudah bisa menggunakan bentuk jamak secara tepat, menggunakan bentuk kata lampau dan menggunakan beberapa awalan. Periode keenam anak berlansung pada usia tiga sampai empat tahun. Anak sudah bisa mengucapkan kalimat yang terdiri dari tiga sampai empat kata. Anak juga sudah bisa menggunakan kalimat pertanyaan ya dan tidak, serta menggunakan kalimat perintah dan negatif. Pemahaman anak terhadap bahasa semakin bertambah. Periode ketujuh berlansung pada anak berusia lima sampai enam tahun. Kosakata anak rata-rata kurang lebih mencapai 10.000 kata, kalimat yang diucapkan anak masih kalimat sederhana. Periode kedelapan berlansung saat anak berusia enam sampai delapan tahun. Kosakata terus bertambah dengan sangat cepat dan anak sudah lebih ahli menggunakan aturan kalimat, keahlian atau kercakapan berbahasa anak semakin meningkat. Periode kesembilan berlansung saat anak berusia sembilan sampai sebelas bulan, anak sudah bisa menentukan sinonim kata dan strategi berkomunikasi terus bertambah. Periode kesepuluh berlansung saat anak berusia sebelas sampai empat belas tahun. Kosakata anak tidak hanya mencakup kata-kata konkret tetapi anak sudah bisa memahami kata abstrak. Sudah mulai bisa memahami bentuk kalimat yang komplek. Anak sudah memahami fungsi kata dalam kalimat, memahami kata metapora atau kiasan. Periode kesebelas berlansung saat anak berusia lima belas sampai dua puluh tahun. Anak sudah dapat memahami karya 
sastra seperti puisi, syair dan lainnya (Santrock, 2004).

Jadi secara umum, menurut ahli perkembangan bahasa hampir sama tiap periode usia anak, yang membedakan hanya pembagian atau rentang dari masa perkembangan tersebut. Santrock periode perkembangan bahasanya lebih detail atau lebih lengkap dibandingkan dengan pembagian menurut ahli yang lain.

\section{Perkembangan Sosio-emosional Masa Kanak-Kanak Awal Diri, harga diri dan perkembangan identitas}

Diri atau aku adalah sesuatu yang unik dan tidak tercampur dengan orang lain. Sedangkan harga diri adalah pandangan keseluruhan seseorang terhadap dirinya. Carl Roger mengatakan bahwa orang memiliki harga diri rendah karena tidak diberi dukungan emosional dan peneriman sosial yang memadai. Harga diri ini bisa berubah dan bisa menetap tergantung kondisi. Secara umum ketika menginjak usia remaja penelitian menunjukkan bahwa harga diri perempuan turun $2 \mathrm{x}$ lipat dibandingkan pria. Perkembangan identitas ini terjadi pada usia remaja menjelang dewasa, sehingga masa ini dikenal dengan masa pencarian identitas. Identitas terkait dengan eksplorasi dan komitmen yang menunjukkan penerimaan seseorang terhadap satu identitas dan menerima konsekuensi dari identitas tersebut (Santrock, 2004).

Terdapat empat model identitas yaitu: Model pertama adalah model identity diffusion yaitu identitas seseorang sebelum mengalami krisis. Model kedua adalah model identity foreclosure, sedikit lebih komplek dari model pertama. Model ini terjadi saat individu sudah membuat komitmen tetapi belum mengalami krisis. Model ketiga adalah model identity moratorium, model ini saat individu berada ditengah krisis tetapi komitmen mereka belum ada. Model keempat adalah model Identity achievement, saat individu telah mengalami krisis dan telah membuat komitmen. Dari empat model ini, model yang keempat ini dikatakan sudah stabil yaitu sudah teruji oleh krisis dan sudah adanya komitmen.

\section{Perkembangan Moral}

Perkembangan moral memiliki kaitan dengan aturan, konvensi yang menyangkut interaksi seseorang dengan orang lain. Interaksi ini harus bersifat adil dan diatur dengan aturan yang jelas. Penekanan aturan tersebut adalah bagaimana individu bisa merasakan secara moral. Berikut diuraikan beberapa teori tentang tahap perkembangan moral atau emosional menurut ahli, di antaranya adalah:

1) Teori Piaget

Menurut Piaget tahapan perkembangan emosional anak dibagi dalam tiga masa atau tahap yaitu: Tahap pertama adalah tahap Heteronomous morality. Tahap ini berlansung saat anak berusia empat sampai tujuh tahun. Pada tahap ini anak menganggap aturan dan keadilan sebagai bagian dari dunia yang tidak bisa di ubah dan tidak bisa dikontrol. Jika seseorang melanggar maka anak percaya mereka lansung akan dijatuhi hukuman. Tahap ini, orang tua memiliki peran penting dalam perkembangan moral anak. Tahap kedua adalah tahap transisi, berlansung pada saat anak berusia tujuh sampai sepuluh tahun. Tahap ketiga adalah tahap Autonomous morality, tahap ini berlansung pada saat anak berusia sepuluh tahun sampai dewasa. Pada tahap ini anak mulai mengetahui dan memahami bahwa hukum dan aturan dibuat oleh manusia. Anak sudah tahu bahwa hukuman dikenakan melalui medium sosial jika tidak ada yang melihat maka hukuman dapat dihindari. Menurut Piaget orang tua pada periode ini tidak terlalu memainkan peran penting dalam perkembangan moral anak karena 
mereka bisa mengatur diri mereka secara otoriter.

2) Teori Kohlberg

Kohlberg mengatakan bahwa konsep utama perkembangan moral dalam teorinya adalah internalisasi nilai-nilai moral. Idealnya perilaku dikontrol secara internal bukan oleh faktor eksternal. Jadi kesadaran berperilaku berasal dari diri sendiri bukan orang lain. Kohlberg menyusun teori perkembanganya ke dalam tiga level dan dua tahap setia levelnya yaitu:

a. Level 1 adalah level Prakonvensional, pada periode ini belum ada internalisasi nilai moral dalam diri anak. Level ini terbagi dalam dua tahap yaitu: Tahap 1 Heteronomous morality. Pada tahap ini anak patuh kepada orang dewasa yang menyuruhnya patuh karena takut pada hukuman bukan karena kesadaran. Tahap 2 individualism, tujuan dan pertukaran. Pada tahap ini individu atau anak melakukan kepentinganya dan begitu juga dengan orang lain. Kebenaran menurut anak ketika melibatkan pertukaran yang seimbang.

b. Level 2 adalah level konvensional, sudah ada intenalisasi yang disebut dengan internalisasi pertengahan atau masih sebagian. Level ini dibagi dalam dua tahap juga yaitu: Tahap 3 Individu atau anak percaya diri, sangat perhatian dan loyal kepada orang lain sebagai basis untuk penilaian moral. Hubungan dengan orang lain sangat baik. Tahap 4 merupakan tahap moralitas. Pada tahap ini anak sudah bisa memberikan penilaian moral yang didasarkan kepada pemahaman dan aturan sosial, hukuman, keadilan dan kewajiban.

c. Level 3 adalah Post konvensional, terjadinya internalisasi penuh. Level tiga dibagi dalam dua tahap yaitu: Tahap 5 kontrak sosial atau utilitas dan hak individual. Pada tahap ini individu memahami bahwa nilai, hak dan prinsip mendasari atau mengatasi hukum. Tahap 6 prinsip etika universal, orang telah mengembangkan penilaian moral berdasarkan hak asasi manusia. Ketika berhadapan dengan dilema hukum dan kesadaran mereka mendahulukan kesadaran individu (Santrock, 2004).

Anak yang bagus perkembangan kognitifnya cenderung bagus perkembangan sosioemosionalnya. Hal ini didukung oleh pendapat Lazarus yang mengatakan bahwa emosi mengikuti penilaian kognitif (Ling \& Catling, 2012).

\section{Implikasi Perkembangan kognitif, Bahasa dan sosioemosional terhadap pendidikan.}

Dalam pendidikan khususnya pembelajaran seorang guru harus memperhatikan tingkat perkembang kognitif, bahasa dan sosioemosional anak. Perkembangan setiap anak tidak sama tetapi guru bisa menggunakan tingkat perkembangan yang dikemukakan oleh ahli sebagai acuan. Hal ini dimaksudkan supaya pembelajaran berjalan secara kondusif dan perkembangan anak menjadi optimal. Implikasi Perkembangan kognitif dalam pembelajaran diantaranya adalah: Jika merujuk ke pendapat Piaget maka dalam pembelajaran sebaiknya guru menggunakan pendekatan kontruktivis, peran guru lebih sebagai fasilitator. Guru menggunakan penilaian secara berkelanjutan dan autentik sehingga tidak merugikan anak. Tingkatkan kemampuan akademik anak, dengan merubah ruang kelas menjadi ruang eksplorasi dan penemuan bagi anak. Jika merujuk ke pendapat Vygotsky maka guru harus menggunakan Zone of Proximal Development (ZPD) dalam pembelajaran. Gunakan teknik scaffolding atau bantuan bertingkat, gunakan pembelajaran kooperatif dalam pembelajaran dan pertimbangkan kontek cultural dalam pembelajaran. Pantau dan dorong anak dalam menggunakan privat speech. Penilaian yang dilakukan guru lebih menekankan pada ZPD bukan berdasarkan IQ. 
Implikasi Perkembangan Bahasa dalam pembelajaran diantaranya adalah: menerapkan diskusi dalam pembelajaran, menghargai setiap pendapat anak, menggunakan sesi pembelajaran untuk meningkatkan kosakata anak, dan menggunakan proyek yang dapat melatih kemampuan bahasa anak.

Implikasi Perkembangan Sosioemosional dalam pembelajaran diantaranya adalah: Guru menghargai dan menekankan tentang kebutuhan orang lain. Guru menjadi model dalam berperilaku atau dapat menjadi teladan dalam berperilaku yang bisa ditiru oleh anak. Beri label dan identifikasi perilaku prososial dan anti sosial, sehingga anak bisa memahami perilaku tersebut. Beri penguatan dan reward kepada anak yang berperilaku positif, sehingga mereka termotivasi untuk terus melakukanya. Guru memperhatikan dan mendorong perilaku sosial anak dengan bijak dan bantu anak untuk mengambil sikap dan dapat memahami perasaan orang lain. Gunakan strategi disiplin yang baik, sehingga anak terbiasa melakukanya tampa terpaksa. Pimpin diskusi tentang interaksi prososial dan kembangkan proyek kelas dan sekolah yang bisa mengembangkan sosioemosional anak.

\section{KESIMPULAN DAN SARAN}

Perkembangan kognitif menyangkut perkembangan dalam pemikiran. Teori perkembangan kognitif yang terkemuka dan sangat berpengaruh terhadap teori perkembangan kognitif yang lain adalah teori perkembangan kognitif Piaget dan teori perkembangan Vygotsky. Teori perkembangan kognitif Piaget mengatakan bahwa tingkat perkembangan anak dibagi kedalam empat tahap dan terdapat lima konsep dasar yang menjadi acuan perkembangan kognitifnya yaitu: Skema, Asimilasi, Akomodasi, Organisasi dan Ekulibrasi. Sementara Vygotsky menekankan bahwa perkembangan kognitif sangat ditentukan oleh perkembangan bahasa. Teori ini berpijak kepada Zone of Prokximal Development disingkat dengan ZPD yaitu serangkaian tugas dengan batas yang dapat dikerjakan oleh anak atau dapat dikerjakan anak jika dibantu oleh orang dewasa atau anak lain atau teman sebaya yang lebih mampu secara kognitif. Penekananya ada pada pengaruh sosial terhadap kecerdasan anak. Sesuai dengan konsep ZPD tersebut ada istilah scaffolding yaitu sebuah teknik memberikan bantuan dengan mengubah bentuk dukungan bertahap sampai anak mampu mengerjakan tugas tersebut. Perkembangan bahasa menurut ahli erat kaitan dengan perkembangan kognitif. Anak yang memiliki perkembangan kognitif yang baik cenderung memiliki kemampuan bahasa yang baik juga. Begitu juga dengan perkembangan sosioemosional. Perkembangan ini saling terkait dan memiliki hubungan linear.

Berdasarkan uraian di atas, perlu diadakan penelitian lebih lanjut terkait hubungan antara perkembangan kognitif, bahasa dan sosioemosional anak serta implikasinya dalam pembelajaran.

\section{DAFTAR PUSTAKA}

Brata, S. S. (2001). Psikologi Pendidikan . Jakarta: Raja Grafindo Persad.

Ling, J., \& Catling, J. (2012). Psikologi Kognitif; edisi terjemahan. Jakarta: Erlangga.

Santrock, J. W. (2004). Psikologi Pendidikan; edisi terjemahan. Jakarta : Prenadamedia Grup.

Soemanto, W. (2006). Psikologi Pendidikan. Jakarta: Rineka Cipta.

Surna, I. N., \& Pandeirot. (2014). Psikologi Pendidikan. Jakarta: Gelora Aksara Pratama.

Syah, M. (2009). Psikologi Belajar. Jakarta: Rajawali Press. 